\title{
REGISTERED CRIME HOT SPOTS IN OSTRAVA - LOCATION, DEVELOPMENT AND INFLUENCING FACTORS
}

\author{
Igor Ivan, Jiř́í Horák* \\ * Institute of Geoinformatics, Faculty of Mining and Geology, VSB - Technical University of Ostrava, \\ 17. listopadu 15, 70800, Ostrava, Czech Republic, \\ igor.ivan@vsb.cz, jiri.horak@vsb.cz
}

\begin{abstract}
Registered crime hot spots in Ostrava - location, development and influencing factors

On the basis of individual crime data, spatial analysis of crime development in Ostrava was conducted followed by analysis of potential urban factors influencing the discovered development. The analysis was preceded by a complex semi-automatic process of harmonisation and data geocoding. A combination of automated and expert techniques were utilised using the description of objects, addresses and even selected situations, continuously improving the location quality. With the most precisely located crime incidents, the spatial distribution of crimes was analysed utilising the method of kernel density estimation. Data from 2009 to 2011 were processed and the development and changes of crime distribution over this period were analysed. In Ostrava, 86 located crime hot spots areas were identified and divided into six categories according to annual changes in the areas. Potential urban factors influencing discovered deve-lopment were considered (i.e. number of flats, use of buildings, slot machines, bars). Mainly the number of flats and use of buildings proved to have a significant influence on the prevailing development of crime hot spots.
\end{abstract}

Key words: crime, kernel density estimation, geocoding, criminogenic factors, hot spots; Ostrava, Czech Republic

\section{INTRODUCTION}

Ostrava is the third largest city of the Czech Republic and is located in the north -eastern part close to the borders with Poland and Slovakia. Both the city and the agglomeration have a specific position in criminality, determined by various interconnected fundamental negative factors. The urban character of the agglomeration and the size of the city are a cause of higher crime rates (higher anonymity, dense population, entertainment businesses, potential objects to be stolen, public transport, strong differentiation and the presence of houses, residents etc.), which is further explained, among others, by Schmeidler (2000), Burgess (2008). Another cause of the negative impact on the crime situation in Ostrava is the strongly industrialised character of the city and its agglomeration, as higher crime rates are often observed in industrial cities (due to, for instance, higher migration or lower levels of education). Also, the process of deindustrialisation and the following rise of unemployment and poverty may result in an increase of crime (Illner 2010).

The marked proportion of industry in the employment rate also secondarily leads to an increased risk of unemployment in periods of economic crises. The problem of unemployment and persistently increased unemployment rates in this region is another negative factor. Besides these general factors, specific factors are also present. From a historical perspective, the region of Ostrava has, quite recently, gone through a turbulent industrial, urban and demographic stage. Extensive 
immigration has significantly influenced the population structure but also resulted in a weak relationship to the city and their new homes, lesser social cohesion and a shift from cultural to physical priorities. The impact of migration on the crime rate was proven in an extensive sociological study on the crime rates in Ostrava in the late 1960s (Němcová 1970), where 38\% of all offenders were temporally residents. Another specific factor is the geographic position of the city, in particular, its proximity to the Polish and Slovak borders. In comparison, in 2011 about $80 \%$ of all convicted offenders were residents, $13 \%$ from the Moravian-Silesian Region (out of Ostrava), 4\% foreigners and 3\% were unknown (Horák et al. 2012). Also the influence of the national border remains an important factor for increasing crime levels.

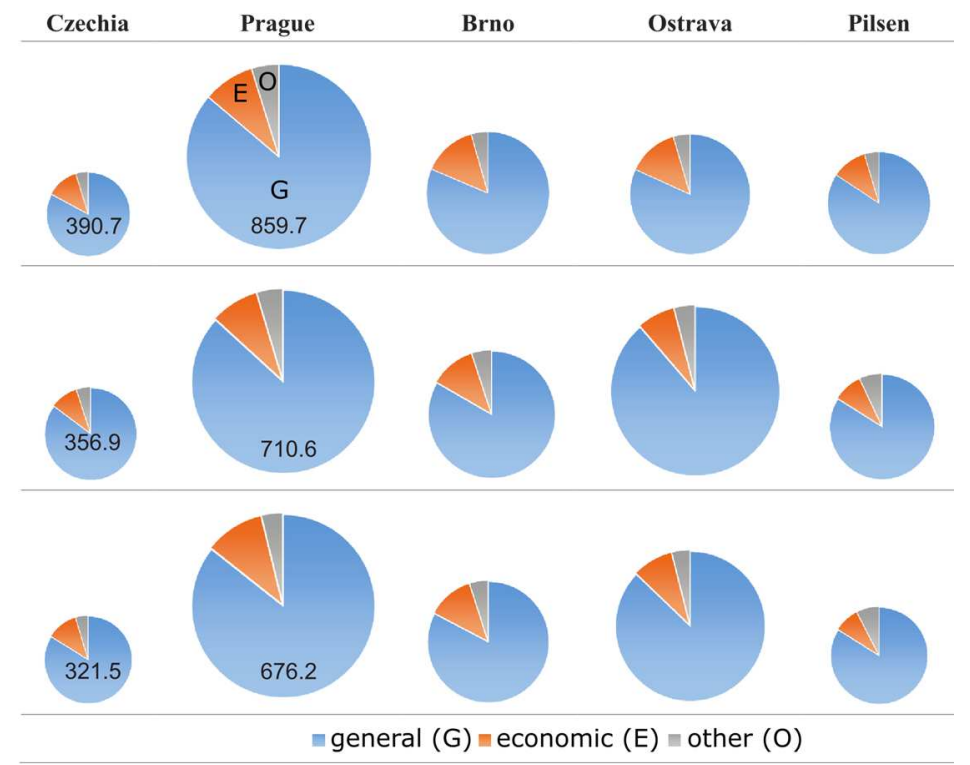

Fig. 1. The intensity and structure of crimes in the Czechia and selected districts in $2005-$ 2007 (first row), 2009 - 2011 (second row) and 2013 - 2015 (third row); perimeter of each circle is proportional to crime index (three-year means; displayed the highest and smallest value)

Data source: Czech Statistical Office (2017).

Registered crime is often quantified using the crime index $(\mathrm{CI})$, that is defined as a number of crimes per 10,000 people aged 15+ (Novotný and Zapletal 2010). Ostrava also differs in the crime index development when compared to the country average or other big cities. In the Fig. 1, there are crime indexes for the four biggest cities in the Czech Republic together with the national crime index. The area of each diagram is proportional to the CI. Despite an improvement in $2013-2015$ (in all cities), the situation in Ostrava is significantly above the national level, very close to Prague and much worse than in Brno (despite a $27 \%$ higher population in Brno). The general structure of criminality in all cities have remained without significant changes over the years (a small decrease in economic crime shares).

Also, the development of crime in Ostrava follows a worse trajectory in the country. While the national crime index has been on the decline since 1999, except 
two years (2002 and 2007), the crime index in Ostrava was on the rise between the years 2005 and 2013, reaching the level of 1999 in the year 2011 (see Fig. 2). More appallingly, other big cities in the Czech Republic showed a decreasing tendency in this period. Should the years 1999 and 2009 be compared, then all big cities in the Czech Republic observed a decrease in the crime rates. In Ostrava, however, the change was minimal $(0.2 \%)$, while the crime rates in Prague, for instance, dropped by $35 \%$ over the same period. Since 2009 , the crime rates in the Ostrava district have fallen slightly (mainly in 2012), and after the last increase in 2013, probably caused by the amnesty of the former president (1. 1. 2013), there was an evidently significant decrease in 2014 and 2015 (a bigger decrease than for the Czech Republic or the Moravian-Silesian Region).

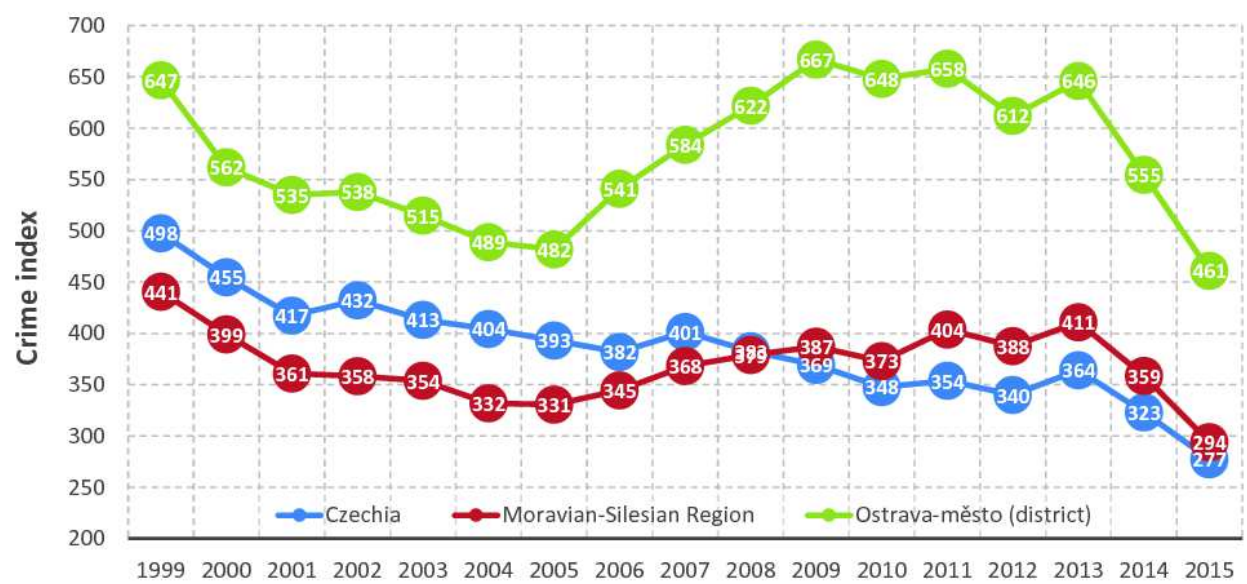

Fig. 2. Development of CI in Czechia, the Moravian-Silesian region and Ostrava district in $1999-2015$

Data source: Czech Statistical Office (2017).

Regional differences in crime and its progress traditionally attract geographers. In Czechia and also Slovakia, there are quite common statistics about the crime situation on the level of regions (NUTS3) or districts (LAU1). These general statistics should be considered by geographers in the 21 st century as not detailed enough. Crime has not the same intensity over the whole area but differs among municipalities, urban zones and streets. This paper aims to demonstrate an analysis identifying crime hot spot areas utilizing data about all registered crime incidents committed in Ostrava between 2009 and 2011. This methodology is followed by the analysis of spatiotemporal development. Additionally, the positive or negative influence of selected urban factors on this development have been considered too. Although this individual data provides a great potential for various analyses, it also creates a great danger of misinterpretation, if the data that this paper describes in detail, is not rigorously pre-processed and processed. All presented results are purposely displayed above blank maps because of the agreement with the Police of the Czech Republic. 


\section{CRIME RESEARCH IN CZECHIA AND SLOVAKIA}

A detailed historical development of the relationship between crime analyses and geography in Czechia has been provided by Jíchová (2014). Czech and Slovak geographic studies published during the last two decades dealing with a crime can be divided into two categories. The first group deals with crime incidents that are registered and published by the police in official statistics. These studies work mainly on the smaller geographical scale and analyse crime distribution, structure and development mainly on the level of districts (Lubelcová 1996 and Michálek 1995, 2009 and 2010). Additionally, relationships between the level of crime and various demo-economic indicators (population, age structure, unemployment, wages, etc.) are often studied. The current level of crime as well as its progress and crime structure on the level of police districts in Czechia are published online on the web map portal Mapakriminality.cz (Fig. 3). However, papers dealing with macro-level crime analyses in Czech geography journals are very rare. Trends in crime development in Czechia are annually published by the Institute of Criminology and Social Prevention (the latest is Marešová et al. 2015) but from the geographical point of view, regional differences are only generally compared on the level of NUTS3 regions.

Studies analysing crime on a micro-level and working with individual crime incidents have not been published mainly because of problems with the official data available and its quality. Michálek (1997) belongs to one of the first studies focused on a more detail geographical level. Martinková (2007) analysed the experience of respondents with a crime but without spatial factors. Micro-level analyses of registered crime incidents were published by Horák et al. (2011, 2012 and 2013). This paper further extends findings from these three studies and analyses spatial distribution of crime incidents and its development in the city of Ostrava (in relation to the aim of the paper).

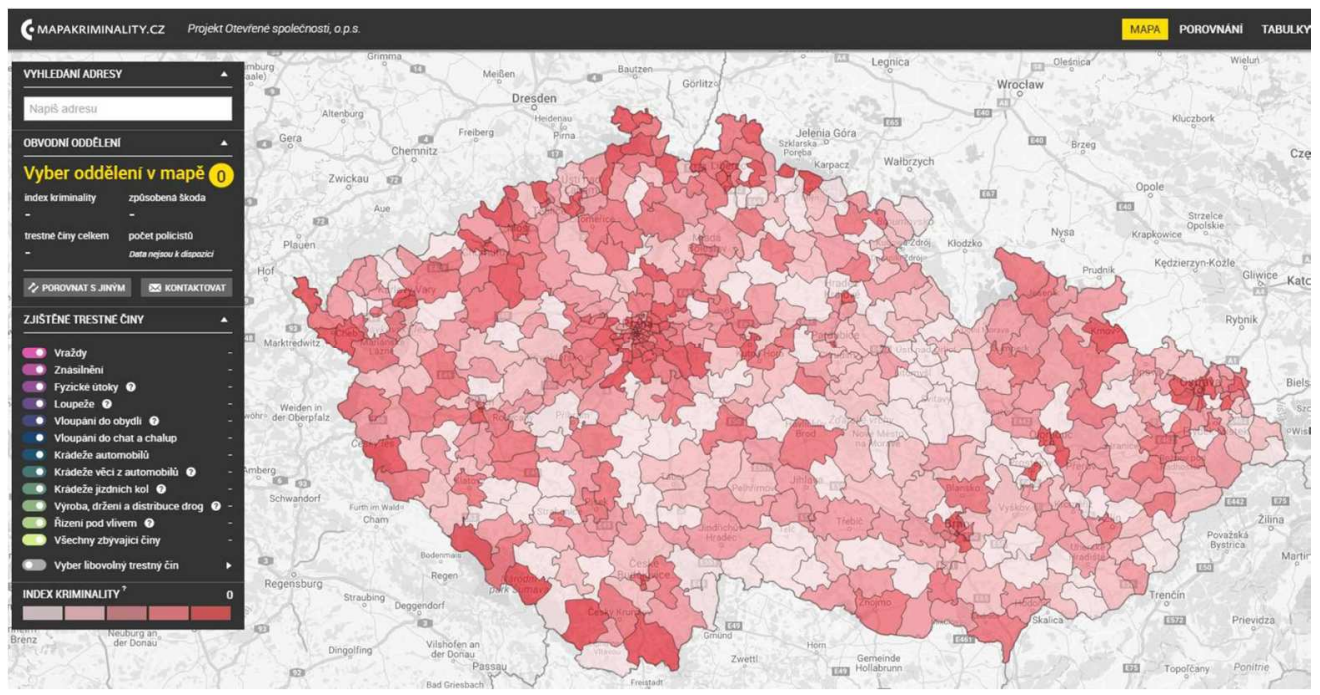

Fig. 3. Web Map Portal Mapakriminality.cz (level of crime in police districts in November 2016) 
The second type of studies that have been very popular during the last few years are focused on the fear of crime and relevant questionnaire surveys. Matlovičová (2010) analysed fear perception in Prešov. Stasíková (2011 and 2013) analysed factors causing fear in Petržalka. Fear of crime in Prague and its districts were deeply studied by Jíchová and Temelová (2012) or by Temelová et al. (2016). Pánek et al. (2016) analysed fear of crime in Olomouc using web-based crowdsourcing tool PocitoveMapy.cz. They continue with analysing other Czech cities (Opava and Jihlava). These papers often recommend also possible solutions on how to decrease the level of fear or how to prevent crime incidents. Matlovičová and Mocák (2014) describe the possibilities to apply CPTED (Crime Prevention Through Environmental Design) to the intra-urban criminality on the example of the city of Prešov.

\section{DATA SOURCE AND PROCESSING}

Data from the years 2009, 2010, and 2011 was provided by the Police of the $\mathrm{CR}$. This data contains all registered crime acts (including misdemeanour) within the area of the city of Ostrava. This data does not describe latent crimes which significance varies according to type of crime from single percents in case of murders to $80-90 \%$ in case of vice crimes (MapyKriminality.cz). Geographical location of the acts is described using the attributes of addresses (i.e. municipality, district, street, house number) noted just in the form of free texts. Additionally, the locality is specified in another attribute, comprised of a subjective description by the police officer. The temporal frame is defined through the date and time of the beginning and end of a crime act. The typology of the crime act is defined using official crime classification (codes identifying the specific type of crime acts). The overall procedure of data processing included: verification of data quality and consistency, completion of code lists, verification of selected records, exclusion of specific crime acts ended in some specified manner (i.e. the crime had not been committed).

From the geographer's point of view, the most problematic part of data processing is its location in space - geocoding of records. The accuracy of the records from a spatial perspective varies, mainly due to:

- an unknown location where the crime was committed, even approximate (often crimes committed during travelling, mainly on public transport),

- description of the crime location is too general in the case of a large object (shops, streets, squares, etc.), leading to a higher concentration of crimes in certain points and a larger location uncertainty,

- discord ambiguity (Fisher et al. 2006) of location data, failing to indicate a unique location,

- some recorded acts are connected with crimes committed at multiple locations (several garages or shops).

To improve the resulting quality of geocoding, a database of objects, including their coordinates, was developed. These objects can be identified by the spatial location attributes of records and used to specify precisely the location of a crime act. The database comprises of approximately 3,000 records divided into more than 40 types (not all of them, however, have an official source). They include cemeteries, parks, various accommodation and restaurant facilities, social services, malls and department stores, petrol stations, bars, cultural, health and education facilities and other types of objects. 
The resulting geocoding quality is summarised in Tab. 1 and was discussed in detail in Horák et al. (2013). The majority of records were geocoded using the complete address $(46.5 \%)$. Additionally, a significant part of records (almost $25 \%$ ) were located utilising the developed database of objects. This extensive list of objects considerably contributed to the increase in located records, and that is why their thorough preparation should be emphasised. In the case of $23 \%$ of records, the centre of the street had to be indicated as the crime location, which is inadequate mainly in the case of long streets; however, a more precise result could not be reached through an automated process. Another 3\% of cases were defined through other methods. These included utilising intersections (mainly for traffic crimes), inserting coordinates directly from maps (in the case of some specific areas with internal orientation systems without address system like shopping centres, large industrial areas, university and research areas), the random generating of points along public transport routes and the utilising of coordinates directly from GPS receivers. All the combined ways mentioned above defined the location of $96.5 \%$ cases. Approximately $3.5 \%$ of crime records failed to provide any detailed information about their location and only the municipality or district is recorded. However, such a level of location is too vague for a detailed crime analysis. Hence these records were not located and included.

This automatic process of geocoding was followed by manual modification, where the supplementary text description of the crime location was utilised. Each point was thus manually moved based on the description of the events. Finally, more than $70 \%$ of records were located with a good quality of precision. It is not realistic to achieve a more precise location with such input data quality. It is important to notice that without exhaustive data pre-processing and verification of resulting locations, results might be misleading and publishing such outcomes verge on hoaxing.

Tab. 1. Resulting location of the quality of crime acts in Ostrava (2010 - 2011) (Horák et al. 2013)

\begin{tabular}{lcc}
\hline Type of location & Number of crimes & Proportion (\%) \\
\hline Complete address & 28,015 & 46.5 \\
Location using the database of objects & 14,315 & 23.8 \\
Location using the centre of a street & 13,908 & 23.1 \\
Coordinates from the web map & 941 & 1.6 \\
Intersections & 583 & 1.0 \\
Randomly generated points along the public transport & 288 & 0.5 \\
route & 70 & 0.1 \\
Coordinates from GPS receivers & $\mathbf{5 8 , 1 2 0}$ & $\mathbf{9 6 . 5}$ \\
Located in total & $\mathbf{2 , 1 2 6}$ & $\mathbf{3 . 5}$ \\
Not located & $\mathbf{6 0 , 2 4 6}$ & $\mathbf{1 0 0 . 0}$ \\
Total & & \\
\hline
\end{tabular}




\section{CRIME DEVELOPMENT OVER THE YEARS 2009-2011}

Based on the processed data, the development of structure and the spatial distribution of crimes can be assessed. In 2009, 18,833 crimes were committed, in the following year, the number dropped by $13 \%$, to 16,416 crimes, which did not change considerably in 2011. The CI follows this development and 684, 598, and 589 crimes were committed per 10,000 inhabitants (aged 15+) in the years 2009, 2010, and 2011, respectively.

To identify the hot spots of crime incidents for each year, several methods can be utilised. Anselin's Local Moran statistic (Anselin 1995) or in the case of crime analyses more preferred Gi and Gi* statistics (Chainey and Ratcliffe 2005) can be used for data aggregated to raster or polygonal units. In the case of point patterns, point based methods of spatial clustering are usually applied like the nearest neighbour hierarchical clustering, K-means clustering or density techniques such as kernel density estimations (Levine 2015). The last method was applied for analysing crime data for particular crime types annually and also for analysing the development of crime.

The kernel density estimation (hereafter KDE) is a non-parametric method originally developed to obtain a smooth estimate of a variate or multivariate probability density from a sample of observation in an area of interest (Silverman 1986) without invoking the modifiable areal unit problem (Wong 2009).

$\mathrm{KDE}$ is based on the general formula (Bailey and Gatrell 1995):

$$
\lambda_{\tau}(s)=\frac{1}{\delta_{\tau}(s)} \sum_{i=1}^{n} \frac{1}{\tau^{2}} k\left(\frac{s-s_{i}}{\tau}\right)
$$

where $\lambda(s)$ is the intensity in point $S$ (where $S$ represents general location in area, and $S_{1}, S_{2}, \ldots, S_{n}$ are places of $n$ observed events, $k(u)$ is a suitable function of the dimensional density of probability known as a kernel which has to be symmetrical around the beginning, parameter $t>0$ is bandwidth and determines the level of smoothing, factor $\delta_{\tau}(s)$ depicts a border correction.

There are many functions suitable for kernel implementation e.g. normal, uniform, quartic, triangular, negative exponential (Li and Racine 2007, de Smith et al. 2015 and Levine 2015). One of the most frequent is a quartic function ( $\mathrm{Li}$ and Racine 2007), where:

$$
k_{(u)}=\frac{15}{16}\left(1-u^{2}\right)^{2} \text { for all } u \text { within } \tau
$$

After testing, the cell size was set to 5 metres, as the kernel quartic function was used and the threshold varied regarding the category of crime. Most frequently, this was 150 metres; still, in the case of some crime types, the threshold had to be increased up to 300 metres (Ivan and Horák 2015). This should be applied mainly to those types with low occurrence (e.g. vice crimes, toxicomania). Just values from the highest percentiles of non-zero values were displayed in the resulting maps. Thus the most significant and anomalous localities in the city are displayed. The percentile value changed depending on the category of crime. The value of the last decile of non-zero values was utilised most frequently. However, it had to be raised 
in some cases, mainly in the case of crimes that are concentrated in isolated areas (more information in Ivan and Horák 2015).

The KDE is less suitable for crimes with a sparser occurrence, as the proximity of individual incidents is not within the given threshold and their intensities cannot be calculated. It is, therefore, sufficient to display just particular occurrences. Here, however, legislative restrictions for displaying this data may apply, which requires applying other methods of visualisation or data masking (Kounadi and Leitner 2014).

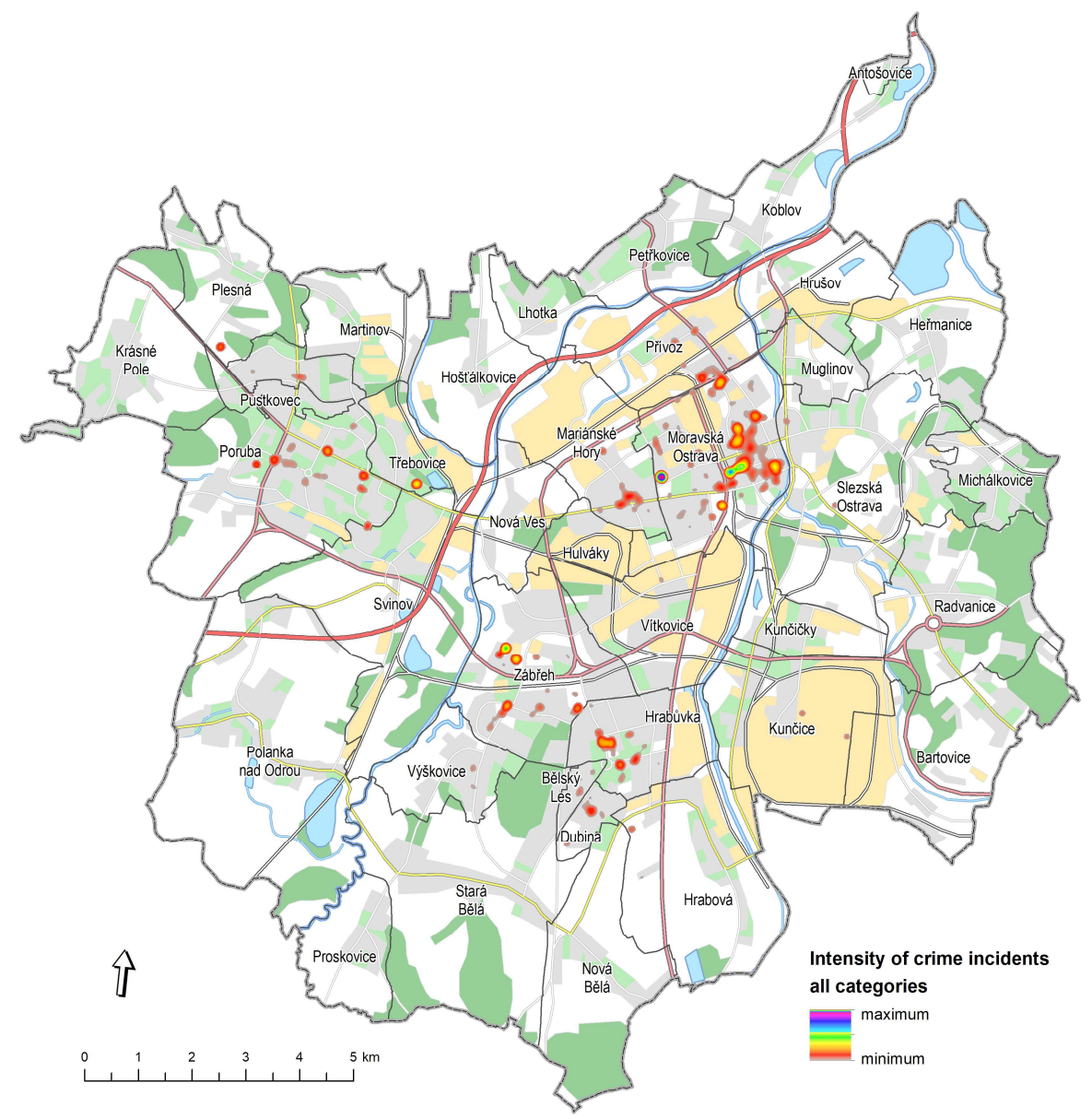

Fig. 4. Crime incident intensity (the last decile of non-zero pixels) in Ostrava in 2011 (modified from Horák et al. 2013)

The KDE map for the situation in 2011 (Fig. 4) represents an appropriate method for the prompt location of problematic locations. However, it is necessary to conduct a more in-depth analysis of crimes that have occurred in such areas to differentiate between areas with a criminogeneous factor or highlighted due to an exceptional or anomalous event. The publishing of these results must be confirmed 
by the Police of the Czech Republic. Their presentation is a sensitive issue due to a variety of reasons, ranging from privacy protection to possible impacts on the realestate market.

The KDE method with the settings mentioned above was also utilised in assessing the development of crime acts (Fig. 5 and 6). The settings remained unchanged for all analysed years. Localities with a high crime intensity were delimited using contour lines joining pixels with the value of the last decile of all nonzero intensities (Lewis 2015). The map (Fig. 5) shows the development of crime intensity in one part of Ostrava over the three analysed years (using contours), along with the KDE of the crime of the whole three-year period (using colour ramp); similar to Inspektor et al.(2014).

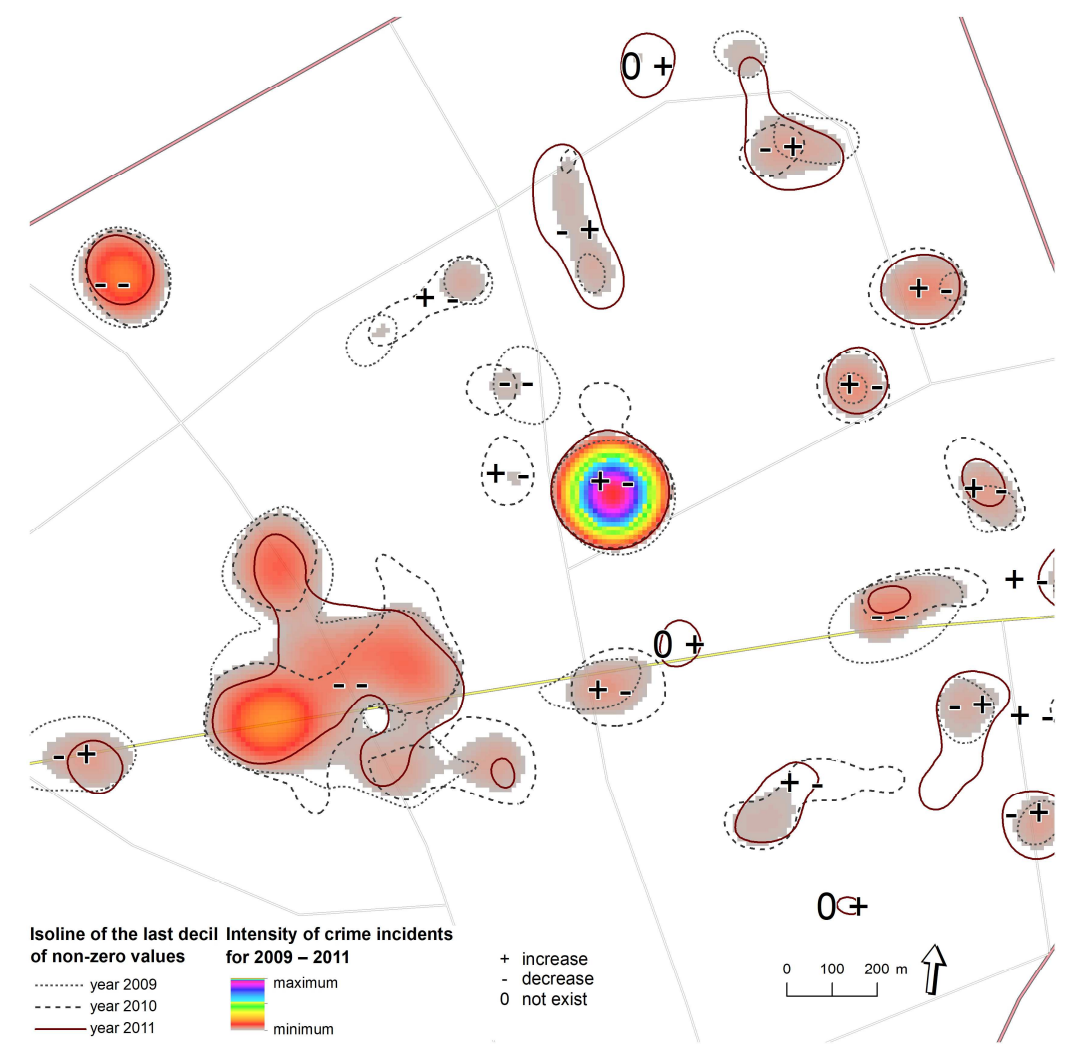

Fig. 5. Development of crime intensity (the last decile of non-zero pixels) - selected part of Ostrava $(2009-2011)$

In total, 86 hot spots were located over the whole period, in which the change in area between years was compared (see Fig. 6). There were cases when the located hot spots either merged or divided into individual locations. In such case, partial polygons were merged into multipart polygons. This ensured the comparability of results over the three years. Crime significantly dropped between the years 2009 and 2010 , followed by a moderate decrease in the next year (Tab. 3). The compari- 
son of the resulting hot spot locations, however, fails to display the change in the volume of crimes, but rather changes in their spatial distribution - emergence or disappearance of hot spots.

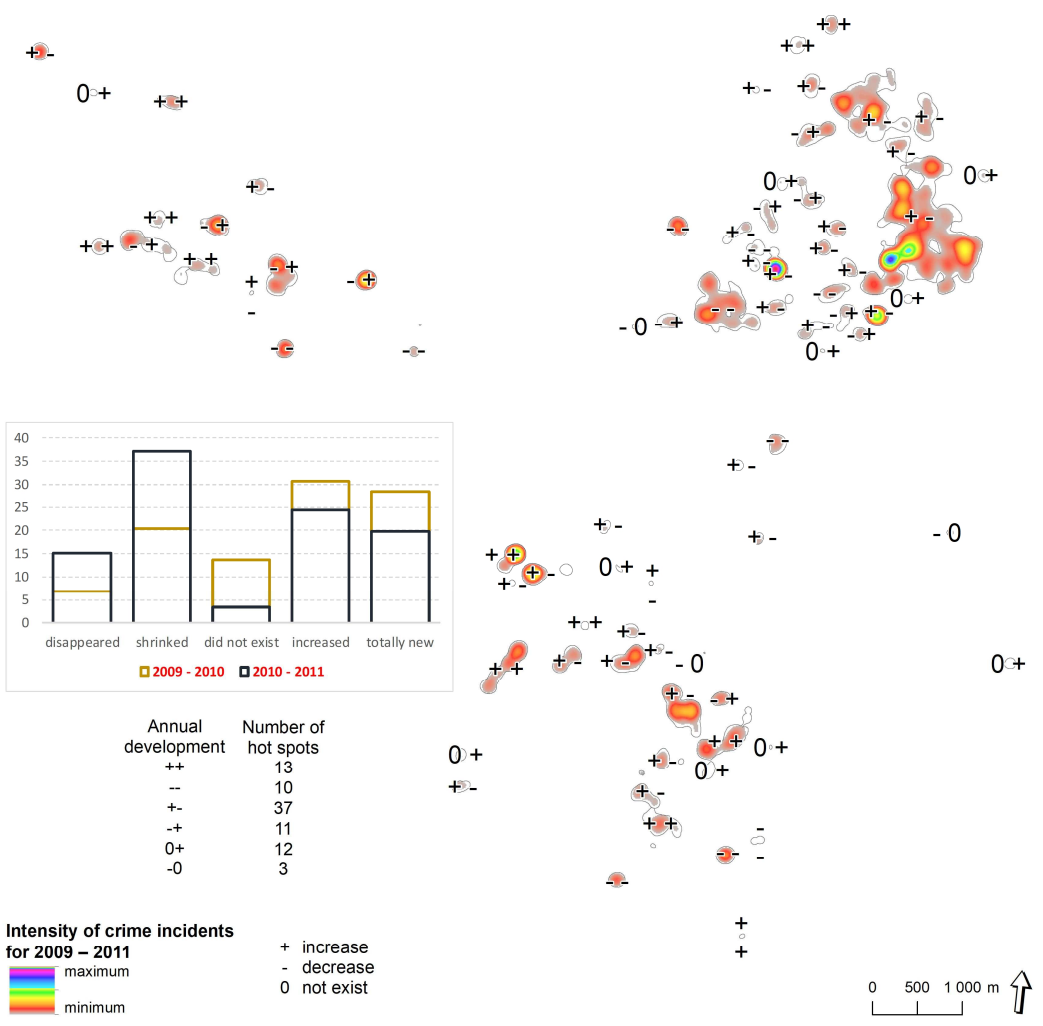

Fig. 6. Development of crime intensities (the last decile of non-zero pixels) in Ostrava (2009 - 2011)

Tab. 3. Areas of crime hot spots in hectares (2009 - 2011)

\begin{tabular}{lccc}
\hline Statistics & 2009 & 2010 & 2011 \\
\hline Count & 51.00 & 68.00 & 69.00 \\
Mean & 3.16 & 3.61 & 3.48 \\
$5 \%$ trimmed mean & 1.66 & 2.04 & 2.07 \\
Median & 0.55 & 1.49 & 1.28 \\
Std. deviation & 9.50 & 10.18 & 9.88 \\
Interquartile range & 3.35 & 3.20 & 3.16 \\
\hline
\end{tabular}


Despite the drop in the crime rate in the first two-year period, more than $30 \%$ of hot spot locations observed an increase in the area and $25 \%$ new locations emerged. Consequently, the crime distribution is more dispersed, when already existing locations expanded and completely new ones emerged. By contrast, one fifth of locations shrank, and one tenth failed to comply with the definition of a hot spot location. Medians of areas also confirm this trend for each year, which increased from 0.55 hectares to 1.49 hectares over the years 2009 and 2010 (see statistics in Tab. 3).

In the second period, a moderate decrease in the total volume of crimes was observed but also almost $40 \%$ of hot spot locations reduced in size. Nevertheless, even now $25 \%$ of locations expanded, but the median of their areas decreased to 1.28 hectares (similarly, the mean value). The interquartile range gradually decreases over the whole period, which proves a higher concentration of location areas close to the median value. Should both periods be compared, locations with an increase followed by a decrease in area prevailed. Locations with increasing (or decreasing) areas over both periods show a similar share of approximately $15 \%$.

These changes are also displayed on the map above (Fig. 5) and the development within the whole area of the city in the map below (Fig. 6). Each hot spot location is marked with two characters: + (annual increase), - (annual decrease), or 0 (non-existent in both years). It is evident that the majority of locations with the highest intensity observed the type of "+ -" trend, i.e. an increase followed by a decrease. The only exceptions are locations situated in the western part of the city, where the opposite trend occurred. Ostrava is an example of a polycentric city with three parts of a similar size. In the western part, an increase was observed in 9 locations out of 15 . For the sake of comparison, in the southern part, a decrease occurred in 20 hot spot locations out of 32, and in the centre, the area also decreased in 20 locations out of 33 located. It is impossible to specify whether this is attributed to some movements of offenders, although this is one of the possible hypotheses. Despite a general decrease in crimes, it can be seen that the spatial distribution of each location can have an opposite tendency, as was confirmed in the first analysed period.

\section{URBAN ASPECTS INFLUENCING CRIME LEVEL}

Some authors believe that crime is six times better predictable by location than according to the profile of offenders (i.e. de By et al. 2012). Extensive research has shown that occurrences of crime acts tend not to be randomly scattered in space, but are clustered in certain areas (Curtis 1974, Pyle 1976, Rengert 1980, Swartz 1980, Brantingham and Brantingham 1981, Skogan 1990 and Maltz et al. 1991). This fact helped to define accepted hypotheses according to which the higher risk of crime is in:

1) Urban spaces with an unstable population and a high share of still not adapted immigrants (Roncek 1981).

2) Places with a high social gradient between well-being districts and deprived districts (the concept of the high-risk neighbourhood - Smith 1989).

3) Places with a high concentration of leisure time activities and facilities (Felson 1987, Madge 1997). Usually, it is connected with a high concentration of people (Clark and Eck 2010). 
4) Large living blocks with limited neighbour control (Shaw and McKay 1942).

5) An architecturally monotonic environment (Newman 1972 and Spelman 1993).

6) A modern complex with unclear designated and mutually interlinked free spaces where nobody feels responsibility for events (Newman 1972 in Schmeidler 2000).

7) Other places attractive to commit crime due to creating suitable conditions (i.e. places of prostitution, drug distribution).

To the opposite relatively safety areas are crime neutral places which do not attract offenders nor their victims/targets and where the inherent social control is present (Brantingham and Brantingham 1993).

The verification of general hypotheses about the influences of external factors on the level of crime is problematic because of data availability from the geographical detail, time scale, guaranty and its completeness point of view. This paper deals with individual crime incidents, and that is why only individual data descrybing these factors can be used to analyse possible influences what is very limiting. Finally, a set of available data sources describing urban aspects have been used: type of buildings and the number of flats (both from Register of Census Districts and Buildings records 2013 - Czech Statistical Office), the location of selected points of interests (2014; CEDA), slot-machines (2016; Ministry of Finance) and shops and shopping malls (2015; Incoma GfK). All 86 crime hot spot areas were divided into six groups as described in Fig. 6.

The first considered factor deals with the type of buildings that were divided into industrial buildings (including energy production and storage area), residential buildings, administrative buildings (including public administration, schools, and cultural, educational, sports, social and commercial facilities), other buildings (other than defined in the official code list 75 by the Czech Statistical Office) and buildings with a combined use (i.e. commerce, administrative, residential, recreational purposes). All other building types were excluded because there is no building of such type in a crime hot spot. The relative structure of buildings in crime hot spots were then analysed using contingency tables and adjusted standardised residuals and tested by the Chi-squared test. All adjusted std. residuals were replaced by a sign scheme. These signs highlight the differences from the theoretical distribution according to the level of difference of statistical significance where $+++/---$ represent $99.9 \%$; ++/-- 99\%; +/- 95\% and "o" means that the difference between the observed and theoretical distribution is not statistically significant.

Tab. 4. Influence of building type on crime development

\begin{tabular}{lccccccc}
\hline $\begin{array}{l}\text { Buildings / Type } \\
\text { of crime hot spot }\end{array}$ & -- & -+ & -0 & +- & ++ & $0+$ & $\begin{array}{c}\text { No. of } \\
\text { buildings }\end{array}$ \\
\hline Industrial & $\mathrm{o}$ & $\mathrm{o}$ & $\mathrm{o}$ & $\mathrm{o}$ & $\mathrm{o}$ & $\mathrm{o}$ & 12 \\
Residential & $\mathrm{o}$ & +++ & $\mathrm{o}$ & -- & $\mathrm{o}$ & $\mathrm{o}$ & 1,523 \\
Administrative & $\mathrm{o}$ & -- & $\mathrm{o}$ & $\mathrm{o}$ & ++ & 0 & 322 \\
Other & $\mathrm{o}$ & --- & $\mathrm{o}$ & +++ & --- & 0 & 307 \\
Combined use & $\mathrm{o}$ & $\mathrm{o}$ & $\mathrm{o}$ & $\mathrm{o}$ & $\mathrm{o}$ & $\mathrm{o}$ & 15 \\
Total & 340 & 268 & 6 & 1,326 & 206 & 33 & 2,179 \\
\hline
\end{tabular}


Based on the results in table 4, buildings with a combined use and industrial buildings should be excluded too because of their small count which supports insignificant results. Emerging crime hot spots $(-+)$ are mainly in areas with a high density of residential buildings and on the other side are areas with administrative buildings and buildings of other use. The opposite direction of development $(+-)$ is typical for the prevalence of buildings of other use and with a small share of residential buildings. The last type of crime hot spots consists of areas with a continual increase in crime levels and are typical mainly due to the presence of administrative buildings. There is no statistically significant relationship between the newly emerged, ceased or continuously decreasing hot spots and type of buildings.

The previous table proved the influence of residential buildings on emerging crime hot spots. This influence is analysed in greater detail using the number of flats. From all residential buildings, only those with at least one flat were selected and divided into six categories with one flat (mainly family houses), $2-4$ flats (family houses with more flats and small residential houses), 5 - 9 flats (small residential houses with $3-4$ floors), 10 - 12 flats (medium sized block of flats), $13-$ 21 flats (big block of flats with $4-7$ floors) and 22+ flats (big block of flats with more than 7 floors).

The results prove that residential houses with an only small number of flats (up to 4) are typical for continuously decreasing the level of crime (for all three years) or for hot spots that disappeared in 2011 (even they are only three). Furthermore, their share is smaller than expected in all crime hot spots with an increasing area. Medium sized residential buildings (between 5 and 12 flats) are often in areas with an increase in 2010 followed by a decrease in 2011 . They are not in areas with a continuous increase or in newly emerged hot spots. Areas with an increase in 2011 or with a continuous increase during both years are typical because of the high share of multilevel blocks of flats with more than 13 flats.

Tab. 5. Influence of the number of flats on crime development

\begin{tabular}{lccccccc}
\hline $\begin{array}{l}\text { Number of flats / Type } \\
\text { of crime hot spot }\end{array}$ & -- & -+ & -0 & +- & ++ & $0+$ & Total \\
\hline 1 & +++ & -- & +++ & --- & - & 0 & 128 \\
$2-4$ & +++ & - & 0 & -- & 0 & 0 & 156 \\
$5-9$ & 0 & 0 & 0 & +++ & 0 & -- & 344 \\
$10-12$ & - & 0 & 0 & +++ & --- & 0 & 241 \\
$13-21$ & --- & +++ & 0 & 0 & +++ & 0 & 276 \\
$22+$ & --- & ++ & 0 & -- & +++ & +++ & 287 \\
Total & 211 & 226 & 3 & 817 & 150 & 25 & 1,432 \\
\hline
\end{tabular}

To describe the potential criminogenic factors and confirm or reject some of other hypotheses defined at the beginning of this chapter, several types of point of interest were used - slot machines, bars, shopping malls, supermarkets (Albert, Billa, Globus, Kaufland, Lidl, Penny Market and Tesco), basic schools and high schools. Unfortunately, due to the used individual data, the data's years of publica- 
tion differs more or less from the crime data. This discrepancy in years can mean that the data does not completely reflect the situation in $2009-2011$. The most significant impact is in the case of slot machines where many of slot machines have been removed due to bans by city-district authorities since 2011. Nevertheless, in the case of other types of objects, it would not be so problematic.

Table 6 contains the densities of objects in crime hot spots according to their change in area and the total share of objects in crime hot spots areas from all objects of that type. Probably due to different years of data sources, there is no evident relationship between the development and density of slot machines. However, $64 \%$ of 2,447 slot machines in Ostrava remain in crime hot spot areas. Also, other types of objects declare a high share of occurrence in crime hot spots (i.e. $55.6 \%$ of all 36 supermarkets) excluding basic and high schools. These shares can be compared to $13 \%$ defining the share of non-residential buildings occurring in these hot spots. Higher or smaller densities of other objects do not significantly influence the development of crime levels. Probably the high share of supermarkets in continuously decreasing hot spot areas could be caused by the city campaign "Safer Ostrava!!!"” (Bezpečnější Ostrava!!!).

Tab. 6. Density of selected point of interest (per $\mathrm{km}^{2}$ ) in crime hot spots

\begin{tabular}{lccccccc}
\hline $\begin{array}{l}\text { Point of interest / Type } \\
\text { of crime hot spot }\end{array}$ & -- & -+ & +- & ++ & -0 & $0+$ & $\begin{array}{c}\text { Share } \\
\text { of objects } \\
\text { in \% }\end{array}$ \\
\hline Slot-machine (2016) & 130.51 & 345.55 & $1,185.35$ & 738.81 & 540.70 & 342.40 & 64.0 \\
Bar (2014) & 19.40 & 47.88 & 38.66 & 11.79 & $\mathrm{x}$ & 141.22 & 38.2 \\
Shopping mall (2015) & $\mathrm{x}$ & 2.40 & 1.07 & $\mathrm{x}$ & $\mathrm{x}$ & $\mathrm{x}$ & 33.3 \\
Supermarket (2015) & 17.07 & 3.70 & 2.87 & 7.50 & $\mathrm{x}$ & 71.42 & 55.6 \\
Basic school (2014) & 0.51 & $\mathrm{x}$ & 0.06 & 0.90 & $\mathrm{x}$ & $\mathrm{x}$ & 5.3 \\
High school (2014) & $\mathrm{x}$ & $\mathrm{x}$ & 0.03 & $\mathrm{x}$ & $\mathrm{x}$ & $\mathrm{x}$ & 2.1 \\
\hline
\end{tabular}

Note: category - 0 is only informational because of a small number of these areas (3); year in brackets define year of data validity.

\section{CONCLUSION}

The presented crime analysis of Ostrava demonstrates a practical example of the processing of data from police registers. This source of data provides multiple advantages. However, it is the harmonisation process and data geocoding that is quite demanding and decisive for the final quality of the analyses. This includes the geocoding of addresses; nonetheless, some crimes are located in a database using the name of an object (e.g. bars, petrol stations, malls). The database of the object in Ostrava was developed (several thousand records) which significantly contributed to the quality of the geocoding process. The results present only a small part of the information, whose publishing is limited without the agreement of the Police. However, even these results display the hidden potential and interesting aspects of the spatial distribution of crime in Ostrava.

Data for a longer period enables us to analyse the development and thus monitor locations with increased crime intensities. The three-year timeline also provides a 
more stabilised view of crime distribution in the city. Possible influencing factors were considered for all 86 localised hot spots, and a high share of residential houses with more than 13 flats plays the role of an important criminological factor. On the other hand, the crime level in hot spot areas with a majority of residential houses with only $1-4$ flats is decreasing. These confirm the hypothesis stated by Shaw and McKay (1942) and also Newman (1972), Spelman (1993) and others. It is difficult to also confirm other hypothesis defined in chapter five because of a lack of available data. The high share of selected type of objects in crime hot spots areas proved to be typical, especially slot machines (64\% of all in hot spots) and supermarkets $(55.6 \%$ of all in hot spots). However, there is no clear relationship between the development of hot spots and the density of selected points of interest.

To achieve a better interpretation of each location with an increased intensity of crime, it is crucial to mention that it is appropriate to analyse the number of cases compared to the number of people occurring within the given area, not only to residents. Also, the development in particular hot spot locations can markedly differ from the general trend in crime rates for the city. Although crime is on the decrease, the area of most hot spot locations can be increasing, regardless of their intensity levels.

The research is supported by the research of the Czech Ministry of Interior, project No. VF20142015034 "Geoinformatics as a tool to support integrated activities of safety and emergency units".

\section{REFERENCES}

ANSELIN, L. (1995). Local Indicators of spatial association - LISA. Geographical A nalysis, 27, 93-115.

BAILEY, T., GATRELL, A. (1995). Interactive spatial data analysis. Essex (Longman Scientific \& Technical).

BURGESS, E. W. (2008). The growth of the city: an introduction to a research project. In Marzluff, J., Bowman, R., Donnelly, R., eds. Urban ecology. New York (Springer), pp. 71-78. DOI 10.1007/978-0-387-73412-5 5.

BRANTINGHAM, P. J., BRANTINGHAM, P. L. (1981). Environmental Criminology. Beverly Hills (Sage Publications).

BRANTINGHAM, P. L., BRANTINGHAM, P. J. (1993). Environment, routine and situation: toward a pattern theory of crime. In Clarke, R. V., Felson, M., eds. Advances in criminological theory, 5. New Brunswick (Transaction Publishers), pp. 259-294.

de BY, R. A., SUIJKER, P., van OOSTEROM, P. (2012). Maps4Science: An Initiative towards a National Geodata \& Services Facility for Academia. Presented at the Workshop on Testing Geospatial Web Services and Scientific SDIs at the 15th A GILE International Conference on Geographic Information Science, 24-27 April 2012, Avignon, France.

CHAINEY, S., RATCLIFFE, J. (2005). GIS and Crime Mapping. London, Wiley, 442 p.

CLARKE, R. V., ECK, J. E. (2010): Crime analysis for problem solvers in 60 small steps. Center for Problem Oriented Policing, 150 p. [Online]. Available: $<$ http:// www.cops.usdoj.gov/pdf/crimeanalysis60steps.pdf $>$ [accessed: 16 November 2017].

CURTIS, L. A. (1974). Criminal Violence: National Patterns and Behavior. Lexington Books, $231 \mathrm{p}$.

CZECH STATISTICAL OFFICE (2017). Veřejná databáze, [Online]. Available:https:// vdb.czso.cz/ [accessed: 16 November 2017].

FELSON, M. (1987). Routine activities and crime prevention in the developing metropolis. Criminology, 25, 911-932. 
FISHER, P., COMBER, A., WADSWORTH, R. (2006). Approaches to uncertainty in spatial data. In Devillers, R., Jeansoulin, R., eds. Fundamentals of Spatial Data Quality. London (ISTE), pp. 43-59.

HORÁK, J., IVAN, I., OHANKA, J., NÁVRATOVÁ, M. (2011). Analýza kriminality v Ostravě v roce 2009. Ostrava (Vysoká škola báňská - Technická univerzita Ostrava, Institut geoinformatiky).

HORÁK, J., IVAN, I., NÂVRATOVÁ, M, INSPEKTOR, T. (2012). Analýza kriminality v Ostravě v roce 2010-2011. Ostrava (Vysoká škola báňská - Technická univerzita Ostrava, Institut geoinformatiky).

HORÁK, J., IVAN, I., NÁVRATOVÁ, M, INSPEKTOR, T. (2013). Prostorová analýza kriminality v Ostravě 2009-2011. In Inspektor, T., Horák, J., Růžička, J., eds. Sborník z konference GIS Ostrava 2013, 21. - 23. 1. 2013. Ostrava (VŠB - Technická univerzita Ostrava), p. 10.

ILLNER, M. (2010). Deindustrializace průmyslových měst - projevy, příčiny, důsledky a strategie revitalizace. In Hruška-Tvrdý, L., ed. Industriální město v postindustriální společnosti, 1. díl, Ostrava (VŠB - Technická univerzita Ostrava), pp. 9-20.

INSPEKTOR, T., IVAN, I., HORÁK, J. (2014). Mapping and monitoring unemployment hot spots towards identification of socially excluded localities: case study of Ostrava. Journal of Maps, 10, 35-46.

IVAN, I., HORÁK, J. (2015). Metodika identifikace anomálních lokalit kriminality pomocí jádrových odhadů. Certifikovaná metodika. Ostrava (VŠB - Technická univerzita Ostrava).

JíCHOVÁ, J., TEMELOVÁ, J. (2012). Kriminalita a její percepce ve vnitřním městě: př́ípadová studie pražského Žižkova a Jarova. Geografie, 117, 329-348.

JíCHOVÁ, J. (2014). Výzkum zločinu v Česku z pohledu geografie. Historická geografie, 40, 73-93.

KOUNADI, R., LEITNER, M. (2014). Why geoprivacy matters? The scientific publications of confidential data presented on maps. The Journal of Empirical Research on Human Research Ethics, 9(4), 34-45.

LEVINE, N. (2015). CrimeStat: a spatial statistics program for the analysis of crime incident locations ( $v$ 4.02). Ned Levine \& Associates, Houston, Texas, and the National Institute of Justice, Washington, D.C. August.

LEWIS, D. (2015). Kernel density estimation and percent volume contours. In Brunsdon, C., Singleton, A., eds. Geocomputation. A practical primer. London (Sage), pp. 169184.

LI, Q., RACINE, J. S. (2007). Nonparametric econometrics: theory and practice. Princeton (University Press).

LUBELCOVA, G. (1996). Sociálna podmienenost' regionálnej diferencovanosti kriminality na Slovensku. Sociológia, 28, 575-586.

MADGE, C. (1997). Public parks and the geography of fear. Tijdschrift voor economische en sociale geografie, $88,237-250$.

MALTZ, M. D., GORDON A. C., FRIEDMAN, W. (1991). Mapping crime in its community setting: event geography analysis. New York (Springer).

MARTINKOVÁ, M. (2007). Zkušenosti obyvatel Ceské republiky s některými delikty výsledky viktimologického výzkumu. Praha (Institut kriminologie a sociální prevence).

MAREŠOVÁ, A., BIEDERMANOVÁ, E., DIBLÍKOVÁ, S., POŽÁR, J., MARTINKOVÁ, M. (2015). A nalýz a trendů kriminality v roce 2014. Praha (Institut pro kriminologii a sociální prevenci).

MATLOVIČOVÁ, K. (2010). Percepcia bezpečnostného rizika v meste Prešov. Geographia Cassoviensis, 4(2), 98-106.

MATLOVIČOVÁ, K., MOCAK, P. (2014). Intraurbánna kriminalita a jej pevencia v konceptuálnom rámci CPTED (príklad mesta Prešov). Geografický časopis. 66, 199-223.

MICHÁLEK, A. (1995). Priestorová diferenciácia kriminality a vybraných trestných činov v SR (na úrovni okresov). Geografický časopis, 47, 93-108. 
MICHÁLEK, A. (1997). Rizikové areály v Bratislave z aspektu vybraných druhov kriminality. Geografický časopis, 49, 47-62.

MICHÁLEK, A. (2009). Priestorová diferenciácia kriminality. Geografický časopis, 61, 111-120.

MICHÁLEK, A. (2010). Rurálna kriminalita a rurálne okresy Slovenska so zvýšenou kriminalitou. Geografický časopis, 62, 329-345.

NĚMCOVÁ, J. (1970). Kriminalita v Ostravě v roce 1965 a 1966. Praha (Výzkumný ústav výstavby a architektury).

NEWMAN, O. (1972). Defensible space; crime prevention through urban design. London (Macmillan).

NOVOTNÝ, O., ZAPLETAL, J. (2004). Kriminologie. Praha (ASPI Publishing).

PÁNEK, J., PÁSZTO, V., MAREK, L. (2016). Mapping emotions: spatial distribution of safety perception in the city of Olomouc. In Ivan, I., Singleton, A., Horák, J., Inspektor, T., eds. The rise of big spatial data. Lecture Notes in Geoinformation and Cartography. New York (Springer), pp. 211-224. DOI: 10.1007/978-3-319-45123716.

PYLE, G. F. (1976). Spatial and temporal aspects of crime in Cleveland, Ohio. American Behavioral Scientist, 20, 175-197.

RENGERT, G. F. (1980). Spatial aspects of criminal behaviour. In Georges-Abeyie, D. E., Harries K. D., eds. Crime: a spatial perspective. Columbia (Columbia University Press), pp. 47-57.

RONCEK, D. W. (1981). Dangerous places: crime and residential environment. Social Forces, 60, 74-96.

SCHMEIDLER, K. (2000). Prostředí města, urbanistická tvorba a sociální patologie. Kriminalistika, 33, [Online]. Available: <http://www.mvcr.cz/soubor/2000-zip.aspx $>$ [accessed: 16 November 2017].

SHAW, C. R., McKAY, H. D. (1942). Juvenile delinquency in urban areas. Chicago (University of Chicago Press).

SILVERMAN, B. W. (1986). Density estimation for statistics and data analysis. New York (Chapman and Hall).

SKOGAN, W. G. (1990). Disorder and decline: crime and the spiral of decay in American neighbourhoods. New York (Free Press).

de SMITH, M, GOODCHILD, M., LONGLEY, A. P. (2015). Geospatial analysis. a comprehensive guide to principles, techniques and software tools. [Online]. Available: $<$ http://www.spatialanalysisonline.com> [accessed: 16 November 2017].

SPELMAN, W. (1993). Abandoned buildings: magnets for crime? Journal of Criminal Justice, 21, 481-495.

SMITH, S. J. (1989). Social relations, neighbourhood structure, and the fear of crime in Britain. In Evans, D., Herbert, D., eds. The Geography of Crime. London (Routledge), pp. 193-227.

STASÍKOVA, L. (2011). Relevantnost' výskumu strachu z kriminality v urbánnej geografii. Geografický časopis, 63, 325-343.

STASÍKOVÁ, L. (2013). Genius loci vo vzt’ahu k strachu zo zločinnosti na príklade postsocialistického sídliska. Geografický časopis, 65, 83-101.

SWARTZ, R. D. (1980). A spatial analysis of retail/commercial homicides in Detroit: 1968-1974. In Georges-Abeyie, D. E., Harries K. D., eds. Crime: a spatial perspective, Columbia (Columbia University Press), 181-190.

TEMELOVÁ, J., NOVÁK, J., JÍCHOVÁ, J. (2016). Safe life in the suburbs? Crime and perceptions of safety in the new suburban communities in Prague's hinterland, Czech Republic. European Urban and Regional Studies, 23, 677-696.

WONG, D. (2009). The modifiable areal unit problem (MAUP). In Fotheringham, A. S, Rogerson, P. A., eds. The SAGE Handbook of Spatial Analysis. Thousand Oaks (SAGE Publications), pp. 105-124. 


\author{
Igor I van, Jiři Horák
}

\title{
OBLASTI SE ZVÝŠENOU INTENZITOU REGISTROVANÉ KRIMINALITY V OSTRAVĚ - LOKALIZACE, VÝVOJ A OVLIVŇUJÍCÍ FACTORY
}

Kriminalita patří k negativním aspektům lidské společnosti, která je významně prostorově heterogenní a koncentruje se do určitých oblastí. Cílem tohoto článku je prostorová analýza trestných činů na území Ostravy za období r. 2009 - 2011. Ostrava je z hlediska kriminality a jejího vývoje v České republice specifická. Její průmyslová minulost, imigrační vlny, nedávné významné ekonomické strukturální problémy a rostoucí nezaměstnanost mají negativní vliv na úroveň kriminality. Ta dosahuje druhé nejvyšší intenzity napříč všemi velkými městy v Česku (hned po Praze). Rovněž vývoj tzv. indexu kriminality vykazoval rostoucí vývoj oproti stagnaci či mírnému poklesu na republikové či krajské úrovni, ačkoliv od roku 2014 je patrný výrazný pokles i v Ostravě.

Pro analýzy kriminality byla použita data popisující jednotlivé trestné činy na území města. Lokalizace těchto událostí byla v databázi uložena formou volného textu, která nejčastěji obsahovala adresu místa, ale rovněž název objektu (nákupního centra, benzinové pumpy apod.) či název liniového objektu (trasa linky MHD, číslo silnice apod.). Dalšímu zpracování tak předcházel náročný postup harmonizace dat a jejich geokódování. Pro zvýšení přesnosti vlastního geokódování byla vytvořena databáze objektů, která obsahuje více jak 40 typů objektů (obchody, školy, restaurace, benzinové pumpy apod.). Celkem má tato databáze cca 3000 záznamů včetně souřadnic. Výsledná kvalita geokódování je shrnuta $\mathrm{v}$ tabulce 1 . Na adresu je lokalizováno $46,5 \%$ záznamů a téměř $25 \%$ je lokalizováno na konkrétní objekt. V př́padě $23 \%$ trestných činů bylo využito lokalizace na střed komunikace. Následovalo další zpřesňování lokalizace, které spočívalo v ručním posunutí jednotlivých bodů (více jak 60000 bodů) dle doplňujícího popisu výskytu trestného činu. Celkově je více jak 70 \% záznamů lokalizováno na dostačující kvalitativní úrovni. Právě spolehlivá a kvalitní lokalizace trestných činů je stěžejní pro korektnost výsledků následných analýz. Chyby v lokalizaci by mohly způsobovat šírení poplašné zprávy a mít významný vliv mimo jiné na cenu nemovitostí v daných oblastech.

Vzhledem k datům popisujícím vývoj za trríleté období byl analyzován vývoj intenzity trestné činnosti. K tomuto bylo využito jádrového vyhlazování, kdy pro jednotlivé roky byly použity hranice posledního decilu nenulových hodnot. Tyto izolinie vymezily celkem 86 oblastí se zvýšenou intenzitou trestné činnosti za dané tríleté období. Jednotlivé lokality se mezi lety zvětšovaly, zmenšovaly, spojovaly s jinými, tř́štily se, ale také úplně zanikaly či vznikaly. Meziroční vývoj v jednotlivých lokalitách je v mapách vyjádřen znaménky $+\mathrm{a}$ -. Vývoj v počtu a výměre jednotlivých lokalit jde proti celkovému vývoji úrovně kriminality za město. Zatímco $\mathrm{v}$ prvním období celkově poklesl počet trestných činů, tak téměř $\mathrm{u}$ třetiny všech oblastí došlo k nárůstu plochy a vzniklo $25 \%$ nových oblastí. Podobný vývoj byl zaznamenán také v př́ípadě druhého období, ačkoliv medián rozlohy se snížil. Převažuje tak kombinace $+/-$ z hlediska vývoje rozlohy jednotlivých lokalit. Toto potvrzuje, že lokální vývoj se může výrazně lišit od vývoje globálního.

Kromě monitoringu vývoje jednotlivých identifikovaných lokalit byly hodnoceny také vybrané faktory, které mohly ovlivnit jejich vývoj. Problematické se ukazuje nalezení vhodných datových zdrojů v požadovaném prostorovém detailu (individuální záznamy) pro dané časové období a s patřičnou garancí, které by do těchto analýz mohly vstupovat. Byla použita data popisující především urbánní strukturu, a to hlavně typ využití budov, počet bytů v domech pro bydlení a pak řada bodů zájmů (např. výherní automaty, restaurace, školy či obchody). Z těchto analyzovaných faktorů se ukázaly jako obecně významné pro zhoršování situace přítomnost bytových domů, hlavně pak těch s velkým počtem bytů na dům, a administrativních budov. Naopak situace se zlepšovala tam, kde je větší zastoupení budov $\mathrm{s}$ různorodým zaměřením a pokud jsou zde budovy pro bydlení, tak ty $\mathrm{s}$ malým počtem 
bytů. Z hlediska bodů zájmu se neprokázal vliv jednotlivých objektů na konkrétní vývoj jednotlivých oblastí. Nicméně se potvrdilo, že především vysoký podíl automatů a restaurací je typický pro lokalizované oblasti se zvýšenou kriminalitou. Ze všech výherních automatů jich je $64 \%$ v těchto oblastech, v prrípadě restaurací to je 55,6 \%. 
